\title{
Neighbouring perspectives: legal and practical implications of charity regulatory reform in Ireland and Northern Ireland \\ OONAGH B BREEN
}

School of Law, University College Dublin, Belfield, Dublin*

\section{Introduction}

$\mathrm{H}$ istorically, Ireland and Northern Ireland share many similarities in their approach to charity regulation. Existing legislation on both sides of the border dates from the same period (Ireland: the Charities Acts 1961-73; Northern Ireland: Charities Act (Northern Ireland) 1964, Charities Order (Northern Ireland) 1987). The common law's heads of charity are still relevant to the determination of an organisation's charitable status on both sides of the border. ${ }^{1}$ Charity regulation is tax-driven in each jurisdiction with the Revenue Commission in Ireland and HM Revenue and Customs in Northern Ireland playing a major role in the enforcement of charity law, albeit from a purely tax perspective. Remaining oversight responsibilities for charitable organisations are spread across a number of authorities. The Police Service of Northern Ireland and An Garda Síochána adjudicate on charitable fundraising permit applications. The Attorney General acts as parens patriae for charities with the High Court on hand in each jurisdiction to give trustees directions and hear, inter alia, cy-près and sign manual applications. At a more functional level, the Irish Commissioners for Charitable Donations and Bequests (CCDB) adjudicate on cy-près schemes and can approve extensions to charitable trustees' powers whereas similar powers are vested in the Department of Social Development in Northern Ireland. ${ }^{2}$

There are other similarities between the two jurisdictions that are more negatively associated. ${ }^{3}$ Neither jurisdiction currently has an independent statutory regulator of charities like the Charity Commission for England and Wales or its Scottish equivalent, the

This paper owes its origins to thoughts presented at the 13th VSSN/NCVO Annual Conference, Warwick University, September 2007, a venture made possible through a grant from University College Dublin's Seed Funding Scheme. The author would like to thank Patrick Ford, Benjamin Berger and Philip Smith for their helpful comments on earlier drafts of this paper. Responsibility for the views expressed herein along with all errors and any omissions rests solely with the author.

1 Commissioners for Special Purposes of Income Tax v Pemsel [1891] AC 531.

2 See Department for Social Development, Charities in Northern Ireland: Guide for trustees 18th edn (2004), p. 21; see also DCRGA, The Commissioners for Charitable Donations and Bequests, available at www.pobail.ie/en/CharitiesRegulation/CommissionersofCharitableDonationsandBequestsforIreland (last accessed 29 January 2008).

3 See K O'Halloran and O Breen, "Charity law in Ireland and Northern Ireland - registration and regulation" (2000) ILT 6. 
Office for Scottish Charity Regulation (OSCR). There is no up-to-date register of charities. ${ }^{4}$ And although there has been much talk of the need for modernisation of charity law, particularly in the past five years, ${ }^{5}$ neither jurisdiction had until recently embarked upon a statutory overhaul of its charity regulation in the past 20 years (in Northern Ireland's case) or 30 years (in Ireland's case).

Change is at hand, however. The Irish Charities Bill 2007, published in April 2007, lapsed with the calling of the May general election but was restored to the incoming government's legislative agenda. The Bill passed committee stage in January 2008 and report stage is due to be scheduled shortly. ${ }^{6}$ In Northern Ireland's case, the draft Charities (NI) Order 2007 was laid before Westminster in January 2007 but the restoration of devolution in May of that year derailed the regulation's planned passage. Withdrawn as an Order in Council, ${ }^{7}$ a replacement Charities Bill for Northern Ireland was introduced to the Northern Ireland Assembly in December 2007. ${ }^{8}$ This Bill completed committee stage in May 2008 and is expected to receive Royal Assent in July. ${ }^{9}$ Thus, not alone do the two jurisdictions share many similarities in past regulatory endeavours but they are destined to embark simultaneously upon charity law modernisation. Such legislative activity, however, does not exist in a vacuum and the proposed Acts will follow in the wake of similar legislation in neighbouring jurisdictions: Scotland led the way with the Charities and Trustee Investment (Scotland) Act 2005 and a year and a half later, England and Wales followed suit with the enactment of the Charities Act 2006.

We thus stand at a formative moment for charitable change on the island of Ireland. Policy ideas will soon be cast into legislative form thereby radically altering the face of common law charity, as we know it. This paper outlines some of the major changes contemplated by both jurisdictions under the separate headings of substantive law changes (that is, changes relating to the definition of charitable purpose and the test for public

4 The Irish Revenue Commissioners do maintain a list of bodies that enjoy charitable tax exempt status. The information on this list, however, is limited in nature and despite the best efforts of Revenue is not always current.

5 In Northern Ireland, the Minister for Social Development gave a commitment to review the existing charities legislation in 2000. This commitment was followed up on in 2004 with the establishment of an advisory panel to consider legislative reform options and a public consultation on the ensuing proposals occurred in 2005. The Department of Social Development carried out a further public consultation on the Draft Charities Order in 2006, amending it in light of concerns expressed to come up with the $2007 \mathrm{draft}$. Following the Irish Law Society's publication of a major report, Charity Law: The case for reform, in 2002, the Agreed Programme for Government committed that "a comprehensive reform of the law relating to charities will be enacted to ensure accountability and to protect against abuse of charitable status and fraud". In 2003, this commitment took the form of a public consultation paper, Establishing a Modern Statutory Framework for Charities, Consultation Paper (Dublin: DCRGA, December 2003), setting out the principles governing reform. A DCRGA commissioned expert's report on the responses to the consultation followed in September 2004 (O Breen, Establishing a Modern Framework for Charities: Report on the public consultation for the Department of Community Rural and Gaeltacht Affairs (Dublin: DCRGA, September 2004) (hereafter "Breen Report"). The Government approved and published the General Scheme of Bill in March 2006 and this scheme formed the basis for the Charities Bill, published in April 2007.

6 See Dáil Debates, Select Committee Hearings, 22 January 2008.

7 See NICVA, Charity law reform - the situation in Northern Ireland, 22 May 2007 available at www.nicva.org/index.cfm/section/General/key/141205CharReform (last accessed 14 September 2007).

8 See Department of Social Development, "Ritchie introduces charities regulation", press release, 10 December 2007, available at: www.dsdni.gov.uk/index/news_items/charities-regulation-introduced.htm (last accessed 13 December 2007).

9 See Northern Ireland Assembly Debates, Charities Bill, Second Stage, 15 January 2008, available at www.theyworkforyou.com/ni/?id=2008-01-15.3.2 (last accessed 29 January 2008). See also Committee for Social Development, Report on the Charities Bill (30/07/08R), 1 May 2008. 
benefit) in Part II; and regulatory structure changes (concerning the creation of new regulators, new appeal boards and new reporting mechanisms) in Part III. In adopting this functional approach to the Bills, one can assess the proposals' likely consequences for stakeholders in charity regulation (whether the public at large or donors and, in particular, charities, beneficiaries, the state and the courts) and consider the implementation challenges that lie ahead. Although neither proposal is perfect - and there is still time for improvement - there are welcome features in both drafts that should be highlighted.

\section{Substantive law changes}

Both the Irish Bill and the Charities Bill for Northern Ireland introduce for the first time a statutory definition of charity and a test for public benefit.

\section{ChARITABLE PURPOSES - IRELAND}

The Irish drafters have maintained the heads of charity framework originally laid down in the Pemsel case: 10 keeping "the advancement of education" and "the advancement of religion" unchanged; allowing for the "prevention" of poverty in addition to its relief; and retaining the form of the fourth head "other purposes beneficial to the community" but expanding upon it to encompass 11 specific new charitable purposes, similar to those found in the English and Scottish Acts. There is now express reference in the Irish Bill to the charitable nature of advancing community welfare of young, old and disabled people; supporting community development; protecting the natural environment; promoting health; advancing art, science, culture and heritage; and integrating disadvantaged individuals more fully into society. ${ }^{11}$ The Irish Bill will also recognise as "charitable" a body lending assistance to other charities in fulfilling their charitable purpose in an efficient or effective manner. ${ }^{12}$

Unlike the English and Scottish Acts, the Irish Bill excludes reference to both amateur sport and, more surprisingly, human rights in its definition of "charitable purpose". Given the existing tax reliefs for amateur sport in Ireland ${ }^{13}$ and the consistent lack of government enthusiasm to make sport or recreation charitable, ${ }^{14}$ this omission is not unanticipated. The exclusion of human rights, on the other hand, is somewhat more surprising. Although the initial Consultation Paper on Charity Law Reform ${ }^{15}$ did not originally include human rights in the proposed list of charitable purposes, the public's disagreement with this policy decision ${ }^{16}$ led the Department of Community, Rural and Gaeltacht Affairs (DCRGA) to remedy this omission in its 2006 General Scheme of Bill with an express reference to the charitable nature of the advancement of human rights. ${ }^{17}$

No reasons have been publicly offered for the subsequent deletion of the advancement of human rights from the published Bill. The Minister of State for Community, Rural and Gaeltacht Affairs, although promising to return to the issue at report stage, declined to

10 Special Commissioners for Income Tax v Pemsel [1891] AC 531.

11 See s. 3(8)(a)-(k) of the Irish Charities Bill 2007.

12 Committee Stage Government Amendment No. 16, inserting a new s. 3(8)(h) into the Bill.

13 See ss. 235 and 847A of the Taxes Consolidation Act 1997.

14 There is no equivalent in Ireland to the English Recreational Charities Act 1958. See O Breen, "Taxing considerations - levelling the playing fields of charity" (2001) 6(4) Conveyancing and Property Law Journal 76.

15 DCRGA, Establishing a Modern Statutory Framework (n. 5 above).

16 See Breen Report (n. 5 above), p. 21, noting that a "significant number of respondents urged that the advancement of human rights should be specifically mentioned as either a heading or sub-heading of charity".

17 See General Scheme of Bill, Charities Bill 2006 (providing in Head 3(1)(d)(v) for "the advancement of human rights, social justice, conflict resolution or reconciliation or the promotion of religious or racial harmony or equality and diversity"). 
speculate on the possibility of human rights ultimately making the list other than to say the matter was being considered by the relevant departments and the Attorney General. It is trite but true to say that the issue will turn upon politics or, at least, a conception of what is "political" and whether political acts, even if not for political purposes, should qualify as charitable. In the absence of an express charitable purpose in favour of human rights, human rights organisations may find no natural home for themselves in the statute other than the broad heading of organisations supportive of "political causes". From a legal perspective, given the existence of so many human rights organisations that pursue charitable purposes, this default labelling - or even the potential for such default classification - is an altogether insufficient categorisation of the promotion of human rights in the context of charity law.

Traditionally, the common law has stopped short of deeming the promotion of "political purposes" as charitable per se. ${ }^{18}$ The courts have interpreted "political purposes" broadly to encompass not just direct support for a political party or political candidate but also any activities that retain, oppose, or change the law, policy, or decision of any level of government domestically or in a foreign country. ${ }^{19}$ The courts refuse to recognise political purposes as charitable because judges cannot determine whether such purposes would be for the public benefit. ${ }^{20}$ The English courts and the English Charity Commission, however, have permitted charities - including human rights charities ${ }^{21}$ - to lobby and to engage in political campaigning when these activities can be said to be an ancillary means for the achievement of the bodies' greater charitable objectives. ${ }^{22}$

Section 2 of the Irish Charities Bill denies charitable status to any "body, the principal object of which is to promote a political party, candidate or cause". 23 The exclusion of bodies promoting "political causes" - a term undefined by the Bill - has caused charities in general to fear that s. 2 will be interpreted to prevent them from lobbying in support of their charitable objectives, that is, that engagement in advocacy activities will result in their

18 See, e.g. Bowman v Secular Society [1917] AC 406; National Anti-Vivisection Society v Inland Revenue Commissioners [1948] AC 31 (HL); McGovern v Attorney General [1982] Ch 321 (Ch D) applied in Wolf Trust's Application for Registration as a Charity [2006] WTLR 1467 (Charity Comm).

19 McGovern v Attorney General [1982] Ch 321 (Ch D); Webb v O'Doherty (1991) 3 Admin LR 731 (Ch D); Southwood v Attorney General (2000) 80 P\&CR D34 (CA). Cf. Public Trustee v Attorney General (NSW) \& Others, NSW Supreme Court, 30 September 1997 (Santow J noting that "if persuasion towards legislative change were never permissible, this would severely undermine the efforts of those trusts devoted to charitable ends that ultimately depend on legislative change for their effective achievement").

20 See Lord Parker in Bowman v Secular Society [1917] AC 406, at 442: "a trust for the attainment of political objects has always been held invalid, not because it is illegal, for everyone is at liberty to advocate or promote by any lawful means a change in the law, but because the court has no means of judging whether a proposed change in the law will or will not be for the public benefit, and therefore cannot say that a gift to secure the change is a charitable gift".

21 See, in particular, Charity Commission for England and Wales, The Promotion of Human Rights, RR12 (London: Charity Commission, January 2005).

22 See McGovern v Attorney General [1982] Ch 321 (Ch D). The Charity Commission for England and Wales published a revised guide on permissible charitable campaigning in 2004 - see Campaigning and Political Activities by Charities, CC9 (London: Charity Commission, September 2004). As a supplement to this revised guidance, in April 2007, the commission published "Campaigning and political activities by charities - some questions and answers" (available at www.charity-commission.gov.uk/supportingcharities/campaignqa.asp, last accessed 13 December 2007) in which it stated that: "We are aware from our work with charities that trustees sometimes exercise a considerable degree of self-censorship in undertaking campaigns, and may not be aware of the extent to which they can campaign and engage in political activities to achieve their objectives. We want charities to be in no doubt about this point."

23 Irish Charities Bill 2007, s. 2, definition of excluded body. 
loss of charitable status. ${ }^{24}$ This interpretation of s. 2 , although understandable, is illfounded. Section 2 is concerned with the objects for which a body is established. It does not exclude organisations that have otherwise charitable objects from using political means (such as lobbying, advocacy etc.) to achieve those charitable ends. If the principal object of an organisation is charitable, it falls outside the ambit of s. 2.25 Given, however, the undefined nature of the term "political cause", s. 2 will make it more difficult for human rights organisations to qualify for charitable status in the absence of an express reference to human rights as a charitable purpose.

The problem with s. 2, as it stands, is twofold. First, it offers no insight into what is meant by the phrase "political cause" that, if found to be a body's principal object, results in its non-eligibility for charitable status. Ultimately, human rights organisations stand to lose the most from this. There is no direct judicial authority on the meaning or scope of the phrase "political cause" to assist the regulator in applying this concept. In a non-charity context, the High Court has interpreted the phrase "political end", drawing upon English charity case law in its exegesis, ${ }^{26}$ but it is unclear whether the terms are synonymous. If promotion of human rights is ultimately excluded from the statutory list of charitable purposes (putting the Irish definition at odds with that of its neighbours, all of which expressly recognise the charitable status of human rights bodies), ${ }^{27}$ organisations in this field would be well advised to set out their objects as precisely as possible in the governing instrument, relating them back to the other established heads of charity 28 and demonstrating the non-political ways in which human rights will be promoted.

A second problem with s. 2 relates to its limits. As discussed above, s. 2 is concerned solely with the purposes for which an organisation is established. It is silent on the extent to which legitimate charities may employ political means to achieve their ends. This silence in itself would not be a problem but for the fact that because the Bill does not elsewhere address the issue of acceptable political means, charities and politicians are conflating incorrectly the two notions of political purposes and political means and expecting s. 2 to

24 See statements of Michael Ring TD and Jack Wall TD during the committee stage of the Irish Charities Bill, 22 January 2008.

25 If anything, a literal reading of s. 2 would appear to extend the possibility of charitable recognition to an organisation that has the ancillary purpose of promoting a political cause - an allowance that goes further than the existing common law, which requires that charities have exclusively charitable purposes.

26 See Colgan v Independent Radio and Television Commission [1999] 1 ILRM 22 in which the High Court defined a "political end" within the context of the Radio and Television Act 1988, as being an activity that is "directed towards furthering the interests of a particular political party or towards procuring changes in the laws of this country or . . . countering suggested changes in those laws, or towards procuring changes in the laws of a foreign country or countering suggested changes in those laws or procuring a reversal of government policy or of particular decisions of governmental authorities in this country or . . countering suggested reversals thereof or procuring a reversal of governmental policy or of particular decisions of governmental authorities in a foreign country or countering suggested reversals thereof.' In reaching this conclusion, O'Sullivan J drew heavily upon the English authority of McGovern v Attorney General [1982] Ch 321 (Ch D).

27 See Charities Trustee and Investment (Scotland) Act 2005, s. 7(2)(j), listing as a charitable purpose “(j) the advancement of human rights, conflict resolution or reconciliation"; see English Charities Act 2006, s. 2(2)(h), listing as charitable " $(\mathrm{h})$ the advancement of human rights, conflict resolution or reconciliation or the promotion of religious or racial harmony or equality and diversity;"; and Charities (NI) Bill 2007, s. 2(2)(h), listing as charitable "the advancement of human rights, conflict resolution or reconciliation or the promotion of religious or racial harmony or equality and diversity".

28 Such organisations, for instance, might try to align their objectives with the charitable heads of s. 3(8)(e) the advancement of conflict resolution or reconciliation or s. $3(8)(f)$ the promotion of religious or racial harmony and harmonious community relations. 
speak to both. ${ }^{29}$ It is, however, important to distinguish these two separate notions of having political purposes (which are not charitable at common law) and employing political means (which, if ancillary to a valid charitable purpose, do not affect charitable status).

The 2006 General Scheme of Bill attempted to deal with the issue of political means by giving statutory legitimacy to certain levels of advocacy undertaken by charities. ${ }^{30}$ Head 3(3) proposed that organisations whose primary focus was advocacy, lobbying or campaigning would not be considered charitable. A charity could engage in these activities, however, if they were ancillary in nature and undertaken solely in furtherance of the charitable purposes of the institution concerned. If carried out in this manner, such activities would not threaten charitable status even if they related to issues which might be considered otherwise to be political. ${ }^{31}$ Not all charities were persuaded of the competency of the new regulator to police advocacy but not intermeddle in charitable affairs. ${ }^{32}$ Bowing to such pressure, the DCRGA (which is the department in charge of charity regulation) removed the advocacy test from the Charities Bill 2007 on the grounds that it did not wish to restrict advocacy by charities. ${ }^{33}$ The removal of the test, however much attributable to the short-term political need to assuage the fears of certain groups that viewed the proposed test negatively, has left a void in the Bill - a void that s. 2 cannot speak to given its concerns with political purposes rather than political means. This void is evidenced by the committee stage proceedings in which deputies repeatedly sought assurances from the Minister of State for Community, Rural and Gaeltacht Affairs that charities could continue to advocate; assurances that would

29 See, in particular, the cross-purpose comments of Minister of State for Community, Rural and Gaeltacht Affairs, Pat Carey, in response to Pat Wall TD and Michael Ring TD with regard to suggested amendments 3 and 4 at committee stage proceedings, 22 January 2008.

30 The guidance on advocacy was prompted by the responses to the public consultation on charity law reform, see Breen Report (n. 5 above), p. 20, in which respondents asked for clarity on the advocacy issue and expressed concern that a failure expressly to enshrine in the legislation the right of charities to engage in advocacy would either deny charities this right altogether or would make it difficult to decipher how much advocacy was permissible by a registered charity, without endangering its charitable status.

31 Heads of Bill, Head 3(3)-(6). This test originated from the recommendations of the Law Society's report on Charity Law (n. 5 above), p. 86, which recommended that a charity should be able to advocate for a change in the law or public policy which reasonably could be expected to help it to achieve its charitable purposes. The Law Society also envisaged that the new regulator would play a key role in providing qualitative (as opposed to quantitative) guidance to charities to assist them in differentiating between "subordinate political activities which further the predominant charitable purpose and party political or propaganda activities which are not ancillary to charitable purposes".

32 An umbrella body for charities and community and voluntary organisations, The Wheel, lobbied against the introduction of the advocacy test. In its analysis of the Heads of Bill in December 2006, The Wheel stated that: "Advocacy by organisations will only be permitted if it is ancillary to its charitable purposes (i.e. undertaken to further one of its charitable purposes). The proposed regulator will have complete discretion in relation to determining whether a charity's advocacy activity is "ancillary" - there are obvious risks here for charitable organisations that engage in significant advocacy activity." See also Kitty Holland, "New law would curtail political role of charities, forum told" (2006) The Irish Times, 1 December, p. 4 (a Wheel-sponsored event at which the danger of allowing the regulator a role in determining what constitutes acceptable advocacy was highlighted).

33 See DCRGA, Principal Features of the Charities Bill 2007 (Dublin: DCRGA, April 2007) in which the department stated that "practical issues" had arisen in protecting charitable status for certain bodies that did good work on the ground, such as those dealing with families of victims of homicide or victims of abuse. In light of this factor and in light of the argument that many charitable organisations legitimately engaged in advocacy as a means to achieve their charitable purpose, though advocacy in itself was not their principal object, the department decided "not to provide for a specific provision in the Bill restricting advocacy by charities". 
have been unnecessary had the advocacy test, the purpose of which was never to restrict advocacy but to give it a legal basis, ${ }^{34}$ remained.

There is a price to be paid for the existing dearth of clear guidance on the extent to which charities may employ political means in the achievement of their charitable objects. This price is extracted in the unnecessary constraints that some charities impose on their activities for fear of crossing an unidentified border with political purposes. ${ }^{35}$ The price is visible also in the structural efforts of voluntary organisations to segregate out their less contentious charitable purposes from charitable purposes that are achieved through advocacy and, thus, might be viewed as suspect in the absence of definitive guidelines. ${ }^{36}$ This "carving out" of tasks for separate legal entities is an allocatively inefficient use of a charity's resources since it changes not the aims of the organisation but only the perception of its form. This artificial veneer of public respectability hides the greater debate that should be taking place on where society should draw the line regarding the use of political means to achieve charitable ends. Section 2, as it stands, is thus a lost battle. It is structured to deal with only half of a problem - political purposes but not political means - and yet it is wrongly interpreted to speak definitively to both. The practical outcome is that there is now no guidance in the Irish Charities Bill on the issue of advocacy, no power for the proposed Regulator to issue guidance on the matter, no case law in Ireland that deals directly with this issue and, therefore, no clarity in the Republic as to what political activities a charity may lawfully engage in without placing its charitable status at risk.

The Irish statutory definition of charitable purpose, when enacted, will be narrower than the English and Scottish definitions because it does not make provision for future purposes to be charitable by either analogy with the new statutory heads (as does the Scottish Act) ${ }^{37}$ or allow for purposes that "may reasonably be regarded as . . within the spirit of" already recognised purposes (as does the English Act). ${ }^{38}$ The only reference to the non-exhaustive nature of the statutory definition of charity is the drafter's use of the word "includes" in s. 3(8) to the effect that elaboration upon "other purposes beneficial to the community" includes the 10 categories of activity listed there but presumably is not limited to these. Whether this wording will be sufficient to encourage the courts, much less the proposed charity regulator, to take a dynamic approach as to what may be considered charitable outside of these headings remains to be seen.

Despite the issues detailed above, the overall expansion of the Pemsel heads in the Irish Bill is to be welcomed. Given the cost of High Court proceedings, there have been few

34 See the Law Society, Charity Law (n. 5 above), p. 85, noting that: "If it is accepted that sometimes, to be effective, charity must not only provide relief, but must question why the system has failed the donees, thereby placing them in the situation of needing assistance in the first place, we recommend that the current absolute prohibition on political advocacy should be reviewed."

35 See K O’Halloran, Charity Law (Dublin: Round Hall, 2000), p. 202, commenting that "the current restrictions on political activity by charities result in some [voluntary] organisations being prevented from obtaining or retaining charitable status, or in choosing to forgo it, even though they undertake charitable work".

36 Some human rights organisations set up subsidiaries to carry out activities that would be recognised as charitable if unconnected to the political advocacy that such organisations often engage in to achieve their human rights objectives. Thus, it is common for a human rights organisation to spin off its goals relating to education, research and dissemination to a separate body and apply for charitable status for that body. See, e.g. the Trust for Civil Liberties, Human Rights and Fundamental Freedoms, the charitable arm of the Irish Council for Civil Liberties (an independent, non-governmental membership organisation working to defend and promote human rights and civil liberties in Ireland).

37 See s. 7(2)(p) of the Charities Trustee and Investment (Scotland) Act 2005 (recognising as charitable "any other purpose that may reasonably be regarded as analogous to any of the preceding purposes").

38 See the English Charities Act 2006, s. 2(4)(b) and (c). 
opportunities for the Irish courts to elaborate on the scope of the common law definition of charity in Ireland. The CCDB have not played a role in this regard with the result that only the Revenue Commissioners have been actively involved in the development of a modern interpretation of "charitable purpose", albeit solely from a tax perspective and with the added disadvantage that Revenue rulings are private to the parties. The provision of a new statutory definition of charitable purpose should free most Irish charities, therefore, from the existing stagnant common law conception of charitable purpose.

\section{CHARITABLE PURPOSES - NORTHERN IRELAND}

The proposed Northern Irish definition of charitable purpose (found in cl. 2) follows closely the broad definition in the English Charities Act 2006 with new references included to the advancement of amateur sport ${ }^{39}$ and human rights. ${ }^{40}$ The Northern Ireland Charities Bill, like the English Charities Act, allows for analogies to be made to existing charitable purposes as well as analogies to the new statutory heads, thereby maintaining greater flexibility in the scope of the statutory definition of charitable purpose than either Scotland does or Ireland proposes to do.

The Northern Irish Bill also provides for a statutory definition of "religion", a definition that includes express reference to faiths that do not profess belief in a god as well as polytheistic religions. ${ }^{41}$ This statutory definition, first seen in the English Charities Act $2006,{ }^{42}$ is cognisant of the multi-cultural make-up of Northern Irish society. This recognition of religious difference goes beyond the law in Ireland, where the definition of religion remains a matter of common law interpretation based primarily on belief in and worship of a supreme being. The proposed statutory definition in Northern Ireland should facilitate the registration of non-theistic organisations (for example, Humanist, Confucian, and even Buddhist organisations) as "religious" charities if they otherwise satisfy the public benefit test in Northern Ireland. Existing practice outside Northern Ireland would seem to suggest that the absence of a similar definition has not affected an organisation's ability to obtain charitable status although it may alter the purpose under which it is recognised. Thus, the Scots recognise polytheism as a valid religious charitable purpose ${ }^{43}$ and Irish case law explicitly extends the constitutional guarantee of freedom of religion beyond monotheistic Christian religions. ${ }^{44}$ With regard to non-theistic bodies, the practice varies: the Irish Revenue Commissioners have granted charitable tax-exempt status ${ }^{45}$ to at least four

39 Charities (NI) Bill 2007, cl. 2(2)(g)

40 Charities (NI) Bill 2007, cl. 2(2)(h).

41 Charities (NI) Bill 2007, cl. 2(3)(a): "religion includes - (i) a religion which involves belief in more than one god, and (ii) any analogous philosophical belief (whether or not involving belief in a god)".

42 See English Charities Act 2006, s. 2 (3)(a).

43 The Charities and Trustee Investment (Scotland) Act 2005 does not define religion other than to note in s. 7(3)(f) that advancement of a philosophical belief is analogous to the advancement of religion. The Scottish register of charities lists as charitable a number of Hindu religious organisations that list advancement of religion as their primary objective. See www.oscr.org.uk/CharityIndexResultsNew.aspx\#results.

44 See Corway v Independent Newspapers (Ireland) Ltd [1999] 4 IR 484, at 502 (SC), Barrington J commenting on the standing of the Muslim, Hindu and Jewish religions under Art. 44 of the Constitution to the effect that Art. 44 "is an express recognition of the separate co-existence of the religious denominations, named and unnamed. It does not prefer one to the other and it does not confer any privilege or impose any disability or diminution of status upon any religious denomination, and it does not permit the State to do so."

45 See www.revenue.ie/pdf/charit_a.pdf, which lists bodies recognised as having charitable tax exempt status up to 7 November 2007 (last accessed 12 December 2007). 
Buddhist organisations, which describe themselves as religious charities. ${ }^{46}$ Humanism, on the other hand, is registered not under advancement of religion but rather under education in both Ireland and Scotland. ${ }^{47}$

A more contentious issue in Northern Ireland is likely to relate to the notion of "designated religious charities". This provision largely mirrors a provision found in the Charities and Trustee Investment (Scotland) Act 2005.48 The Charity Commission for Northern Ireland (CCNI) may recognise a religious charity as a designated religious charity, according to $\mathrm{cl}$. 166 of the Bill, if it satisfies certain conditions including, inter alia, if it has been established in Northern Ireland for at least 10 years and "has a membership of at least 1000 persons who are . . resident in Northern Ireland". The effect of designation is to exempt designated bodies from certain provisions of the Bill, most notably those relating to the CCNI's power to appoint an interim manager, the power to remove or suspend trustees and the power to make specific directions for the protection of the charity. ${ }^{49}$ Although designation can arise only in the case of a religious organisation that has already passed the generally applicable charity test, the existence of a two-tier approach to religious charities was viewed by some as unduly favouring the established Christian denomination religions to the detriment of minority and new faith communities. ${ }^{50}$ In light of concerns raised during committee stage debate, the qualifying criteria for designated status in cl. 166 were subsequently revised with the elimination of a minimum membership requirement; a reduction of the establishment requirement to five years and a new requirement in cl. 16(4)(a) that enjoyment of designated religious status be expressly noted on the Charities Register.

There is one other respect in which the Northern Ireland definition of charitable purpose differs from the statutory definition in England and Wales and that is in the omission of the promotion of the efficiency of the armed forces as an express charitable heading. ${ }^{51}$ Support of the armed forces has long been considered a charitable purpose in

46 The Dublin Buddhist Centre (FWBO); Jampa Ling Trust - Tibetan Buddhist Centre, Cavan; Tara Buddhist Centre, Dublin; and Tibetan Buddhist Religion of Ireland Dzogchen Beara Trust, West Cork. See R v Registrar General exp Segerdal [1970] QB 697 (CA), in which Lord Denning MR viewed the religion of Buddhism as an exception to the general requirement of religion that it should involve reverence to a deity.

47 The Humanist Organisation of Ireland (HOI) is a tax-exempt organisation for charitable purposes under Irish tax law. HOI's Memorandum of Association cites as its main object the advancement of "education and in particular the study of Humanism and the dissemination of knowledge of its principles". (see www.humanism.ie, last accessed 15 January 2008). Similarly, the Scottish Humanist Academy is listed on OSCR as advancing education.

48 See Charities and Trustee Investment (Scotland) Act 2005, s. 64. Note that the Northern Irish provision adopts a lower membership threshold of 1000 residents as opposed to Scotland's requirement of 3000 members, reflecting the size of the province.

49 See Charities (NI) Bill 2007, cl. 165, disapplying cll. 33-6 to designated religious charities.

50 See the comments of Alliance MLA, Anna Lo in the second stage debates of the Charities (NI) Bill 2007 (n. 9 above), noting that: "the Belfast Chinese Christian Church in south Belfast has been in existence for less than 10 years, so it will not be granted religious charity status. The Jewish, Muslim and Baha'i communities may have established their places of worship for longer than the required 10 years, but their membership will not be as many as 1,000; again, they will not be granted designated religious charity status by the Bill."

51 Cf. English Charities Act 2006, s. 2(2)(1), providing that "the promotion of the efficiency of the armed forces of the Crown, or of the efficiency of the police, fire and rescue services or ambulance services" is a charitable purpose. It is perhaps noteworthy that the English Charities Bill, as initiated, had no specific provision for the armed forces. The UK Government's stated position was that promoting the efficiency of the armed forces, which had been a charitable purpose for a very long time, would continue to be a charitable purpose by virtue of the last general description of charitable purposes. However, a Government amendment to include in the list of charitable purposes "the promotion of the efficiency of the armed forces of the Crown" was made on report. See HL Deb 12 October 2005, cols 296-8. 
both England ${ }^{52}$ and Northern Ireland ${ }^{53}$ under the common law Pemsel headings. As Lord Lowry explained in the Royal British Legion case, former members of the defence forces constituted an appreciable section of the community and if the benefit bestowed on that class could be viewed as one that would:

... encourage a person to join the Forces, raise his morale and efficiency while he is serving and help him (and not merely provide recreation and social intercourse) when he returns to civilian life...

Such a benefit could be considered a valid charitable purpose.

The exclusion of the armed forces from the statutory list of charitable purposes in Northern Ireland is not fatal to those charitable associations in light of the rider in the Charities Bill that in deciding whether a purpose is charitable recourse may be had to existing charity law and analogies thereto. ${ }^{54}$ The CCNI will thus be able to refer to existing practice regarding the treatment of organisations set up to support the defence forces and continue to register such organisations as charities provided there is sufficient public benefit shown. ${ }^{55}$ In this way, Northern Ireland is perhaps in a stronger position than Scotland whose Charities Trustee and Investment Act 2005 also omits specific reference to the efficiency and welfare of the armed forces as a charitable purpose. ${ }^{56}$ Unlike Northern Ireland, the Scottish legislation limits analogies for future charitable purposes to the new statutory heads of charity without reference to existing charity law, ${ }^{57}$ which could make it conceivably harder for such an organisation to register as a charity in Scotland. It is noteworthy that OSCR has registered at least one charity that supports the armed forces since the setting up of the Scottish charity register. Gardening Leave, founded in 2007 "to provide relief by means of therapeutic services for men and women

52 See Preamble to Statute of Charitable Uses (1601) 43 Eliz. I c. 4, referring to "releife of ... sicke and maymed Souldiers and Marriners, ... [and] for reliefe or redemption of Prisoners or Captives"; Verge v Somerville [1924] AC 496, at 506 (PC), in which Lord Wrenbury held a gift "unto the trustees for the time being of the 'Repatriation Fund' or other similar fund for the benefit of New South Wales returned soldiers" to be charitable (though not confined to aiding the poor) as being for purposes beneficial to the community, where "New South Wales returned soldiers" were held to be a class of the community.

53 See The Royal British Legion Attendants Company (Belfast) Limited v Commissioner of Valuation [1979] NI 138 (CA).

54 Northern Ireland Charities Bill, cl. 2(4), providing “(4) The purposes within this paragraph . . . are- (a) any purposes not within sub-paragraphs (a) to (k) of paragraph (2) but recognised as charitable purposes under existing charity law or by virtue of section 1 of the Recreational Charities Act (Northern Ireland) 1958 (c. 16); (b) any purposes that may reasonably be regarded as analogous to, or within the spirit of, any purposes falling within any of those sub-paragraphs or sub-paragraph (a) above; and (c) any purposes that may reasonably be regarded as analogous to, or within the spirit of, any purposes which have been recognised under charity law as falling within sub-paragraph (b) above or this sub-paragraph."

55 The UK Government suggested a similar approach in the House of Lords as a reason to reject the amendment to insert specific reference to support of the armed services in the English Charities Bill. However, the Lord Craig of Radley persuaded the Government to reconsider and adopt a "belt and braces" approach at committee stage, HL Debs, 28 June 2005, col. 131, arguing: "the Charity Commission's commentary on the description of charitable purposes in the Charities Bill confirms in paragraph 36: 'The defence of the realm ... such as ... promoting the efficiency of the armed and emergency services' remains a charitable purpose. Some may argue that that is good enough to safeguard [service non-public funds SNPFs]. But that is not the same as having it on the face of the Bill. Others, even the Charity Commission, may find it hard to reconcile the broad sweep and intricacies of the public benefit tests for every charitable SNPF. That possibility could arise. Optimistically, I hope that this would not be the case today. But this legislation will stand for years. Views or public perceptions could change." See n. 51 above.

56 This omission may have been an oversight on the part of the Scottish Parliament. There is no discussion of the role of the defence forces in the parliamentary debates during the passage of the Charities Trustee and Investment Bill and the Bill had become an Act in Scotland before the matter was raised for the first time in the House of Lords as an issue deserving further consideration in regard to the English Charities Bill.

57 See n. 37 above and accompanying text. 
(serving or formerly serving in HM armed forces) who are suffering from mental health problems [and] to educate the general public on the subject of mental health" is registered as a Scottish Charity with the objective of advancing health to beneficiaries in the disabled or mental health area. ${ }^{58}$ The GuideStar UK database, which refers to Gardening Leave's English registration with the Charity Commission for England and Wales, however, classifies the charity under both advancement of health and "the promotion of the efficiency of the armed forces of the Crown, or of the police, fire and rescue services or ambulance services", giving the organisation a broader charitable purpose base in England and Wales than in Scotland. 59

\section{PUBLIC BENEFIT - IRELAND}

With regard to the issue of public benefit, both jurisdictions have eschewed the English approach of leaving the test for public benefit entirely up to the regulator. ${ }^{60}$ The Irish Charities Bill 2007 requires proof of public benefit before a purpose can be declared charitable. The test for public benefit in the Irish Bill, applicable to all non-religious purposes, requires proof of three facts: a) that the purpose in question is intended to benefit the public or section thereof; b) that any private benefit flowing from the purpose is ancillary and necessary for the achievement of the primary charitable purpose; and c) that any donor-imposed limitations on the class entitled to benefit or any charges imposed in the provision of the charitable purpose are justified and reasonable and will not limit unduly the number of persons or classes of person who will benefit. ${ }^{61}$

This public benefit test places greater weight on the meaning of "public" than on the meaning of "benefit". There are no criteria defining what is meant by "benefit" in s. 3. This absence marks a change from the General Scheme of Bill which required a causal connection between the activities carried out and the charitable purpose those activities were intended to advance; in essence, demonstration of benefit in all cases other than religion. ${ }^{62}$ The Irish Charities Bill omits this provision entirely, leaving only the limitation on permissible private benefit as an implicit warning that something more than private benefit is generally required. The Bill focuses instead on the need for proof of the public nature of the benefit. To this end, s. 3(7), in common with the Northern Irish provisions, ${ }^{63}$ abolishes the common law's historical, if anomalous, exceptions for "poor relations" and

58 See the Scottish Charity Register at www.oscr.org.uk/CharityIndexDetails.aspx?id=SC038563 (last accessed 12 December 2007).

59 See GuideStarUK registration details for Gardening Leave at www.guidestar.org.uk/gs_summary.aspx?CCReg $=1119786 \&$ strquery= gardening\%20leave (last accessed 12 December 2007).

60 See, in this regard, Charity Commission for England and Wales, Public Benefit: Charities and public benefit (London: Charity Commission, January 2008) and Charity Commission for England and Wales, Analysis of the Law Underpinning Charities and Public Benefit (London: Charity Commission, 2008).

61 Irish Charities Bill 2007, s. 3.

62 Head 4(2) of the General Scheme of Bill for the Charities Bill, March 2006, provided, "In determining the presence of or potential for benefit, the Regulatory Authority must have regard to: (a) the extent to which the gift may relieve or alleviate the condition giving rise to the charitable purpose, (b) whether the purpose is directed to the public or an appreciable section of the public, (c) whether any private benefit is ancillary, reasonable and necessary to the furtherance of the purpose."

63 See Charities Bill (NI) 2007, cl. 3(2): "in determining whether [the public benefit] requirement is satisfied in relation to any such purpose, it is not to be presumed that a purpose of a particular description is for the public benefit". 
"poor employees" 64 by requiring that the public nature of any such gift cannot be assumed but must be proved if the charity test is to be satisfied.

One area in which the Irish public benefit test will differ from that of Northern Ireland relates to the public benefit requirement for religious charities. Section 3(4) of the Irish Bill provides that once a gift is made for the advancement of religion, that gift is regarded without further proof as being for the public benefit. The all-important determination as to whether a gift actually advances the religion in question is decided according to the laws, canons, ordinances and tenets of the religion concerned ${ }^{65}$ and is not subjected to objective proof. The Dáil (the Irish Parliament) copper-fastened the Irish judicial interpretation of public benefit for religious gifts in the Charities Act $1961^{66}$ and this interpretation lives on today in s. 3(4) of the Irish Charities Bill. Ireland's acceptance of the religious perspective ${ }^{67}$ differs from the approach in Northern Ireland (and England) where there is an insistence on objective proof as to what constitutes public benefit for the advancement of religion. ${ }^{68}$ This divergence is not new, but rather dates back to the late 1800s. The English courts eschew the Irish faith-based approach, ${ }^{69}$ often seeking instead some tangible evidence of evangelism as proof of public benefit. At times this insistence has led the courts to deny charitable status to practices of some established religions that cannot produce physical evidence of benefit in court. ${ }^{70}$ The insistence on evidence of demonstrable public benefit, however, does provide the English Charity Commission with a ready defence to cults and sects that otherwise might seek registration as charities.

A final issue of note with regard to the public benefit provisions is the absence of any statutory definition of "religion" in the Irish Charities Bill. This absence may cause the regulator greater difficulties in Ireland than in neighbouring jurisdictions because once

64 At common law, a very low threshold of public benefit is needed in cases of poverty to establish a charity. Long established anomalies include trusts to benefit one's own poor relations (Isaac v Defriez (1754) 2 Amb 595; Re Scarisbrick [1951] Ch 622), an anomaly extended subsequently to trusts to benefit one's own poor employees (Spiller v Maude (Note) (1881) 32 Ch D 158). Notwithstanding the personal link between donor and donee in these instances public benefit was deemed to be present.

65 Irish Charities Bill 2007, s. 3(5).

66 See Irish Charities Act 1961, s. 45.

67 See Attorney General v Hall \& Byrne [1897] 2 I R 426; O’Hanlon v Logue [1906] 1 IR 247 (holding bequests for masses to be valid charitable gifts); Maguire v Attorney General [1943] 1 IR 238 (holding a bequest to establish a convent for an enclosed order of Catholic nuns to be a valid charitable gift under Irish common law); and Bank of Ireland Trustee Co Ltd and Others v Attorney General [1957] 1 IR 257, at 274-7.

$68 \mathrm{~J}$ C Brady, Religion and the Law of Charities in Ireland (Belfast: NILQ, 1975), p. 95, noting "In the opinion of many Catholics the stairway from the Northern Ireland Court of Appeal to the House of Lords places bequests for masses in jeopardy unless the bequests are coupled with a direction for public celebration providing the element of public edification of which a court can take cognizance." See also NI Committee for Social Development, Report on the Charities Bill (n. 9 above), para. 35, noting: "The Committee had some sympathy with those bodies that felt that the advancement of religion should be presumed to be of public benefit but agreed that there should be no exemptions."

69 Gilmore v Coats [1949] AC 426 (HL), holding that the benefit of intercessory prayer to the public was not susceptible of legal proof and the court could only act on such proof. See also L F H Newark, "Public benefit and religious trusts" (1946) 62 LQR 234; J C Brady, "Some problems touching the nature of bequests for masses in Northern Ireland" (1968) 19 NILQ 357; J C Brady, "Public benefit and religious trusts: fact or fiction" (1974) 25 NILQ 174; C H Sherrin, "Public benefit in trust for the advancement of religion” (1990) 32 Malaysia LR 114; H Picarda, "Religious observances and the element of public benefit" (1993) 2 Charity Law and Practice Review 155; C E F Rickett, "Charities: an anti-Roman Catholic bias in the law of charity?" (1990) Conv 34.

70 Compare the treatment of the bequest in Re Watson [1973] 3 All ER 678 (Ch D), in which Plowman J held that a bequest to publish the religious writings of a Mr Hobbs was charitable on the grounds that the literature although displaying no intrinsic worth had religious tendencies, with the decision of the House of Lords in Gilmore v Coats [1949] AC 426 (HL). 
recognised as a religion, a claimant must show simply that the gift advances the religion in accordance with that religion's own laws in order for the gift to be charitable. What constitutes a "religion" therefore becomes a significant question in the determination of applications from cults, sects and new religions. The absence of statutory guidance effectively passes the buck to the regulator and the Irish courts to determine this matter. ${ }^{71}$

The different approaches of Ireland and Northern Ireland imply that, whereas it will be easier for non-theistic or philosophical belief organisations to come within the heading of "religion" in Northern Ireland, demonstrable public benefit will still be required before charitable registration is possible. For those organisations falling within the common law definition of religion in the Republic, registration as a charity may be easier given the lower public benefit threshold. Thus, newer religions, for example, scientology, ${ }^{72}$ and cults or sects may be in a position to forum shop when it comes to charity registration.

\section{Public Benefit - Northern IRELAND}

Northern Ireland proposes to adopt an approach very similar to that employed in s. 5 of the Charities and Trustee Investment (Scotland) Act 2005. In Northern Ireland, no charitable purpose will enjoy the presumption of public benefit per se. In determining whether a body provides or intends to provide public benefit, cl. 3(3) of the Northern Ireland Charities Bill, as amended at committee stage, provides that regard must be had to:

(a) how any-

(i) benefit gained or likely to be gained by members of the institution or any other persons (other than as members of the public), and

(ii) detriment incurred or likely to be incurred by the public, in consequence of the institution exercising its functions compares with the benefit gained or likely to be gained by the public in that consequence, and

(b) where benefit is, or is likely to be, provided to a section of the public only, whether any condition on obtaining that benefit (including any charge or fee) is unduly restrictive.

This test touches on the two main elements of the public benefit test, namely, whether there is benefit; and, whether the benefit is sufficiently public to be charitable. The proposed test, without setting a minimum threshold for benefit or in any way defining what constitutes "benefit", requires the CCNI to balance off the combined benefit likely to be enjoyed by a charity's members or private individuals minus any detriment that the public is likely to suffer against the overall net benefit that the public will enjoy as a result of the charitable activity in question. One might assume, although this is not expressly provided for in the

71 In this regard, see the committee stage amendment No. 11, offered by Jack Wall TD, to define religion as "not including any organization or cult which in the opinion of the Authority is primarily economic in nature or employs oppressive psychological manipulation of its adherents". In response the Minister of State for Community, Rural and Gaeltacht Affairs, Mr Pat Carey, although rejecting the amendment, promised to seek legal advice and to revert to the matter again at report stage.

72 In the past, the English Charity Commission refused to grant charitable status to Scientology because, in the Commission's view, Scientology's methods of auditing did not advance religion, see Decision of the Charity Commissioners for England and Wales, Application for Registration as a Charity by the Church of Scientology (England And Wales), 17 November 1999. Cf. the decision of the Australian High Court in Church of New Faith v Commissioner of Pay-Roll Tax (1983) 154 CLR 120, which ruled that beliefs, practices and observances of the Church of the New Faith (also known as Scientology) were a religion in Victoria and thus entitled to charitable tax exempt status in that state. 
Bill, that the benefit element of the test will normally be satisfied so long as the balance tilts in favour of more public than indispensable private benefit. ${ }^{73}$

The Scottish Charity Regulator, OSCR, has elaborated on the Scottish public benefit test from which the Northern Irish test is drawn in its recent Guidance Notes on the Scottish charity test. ${ }^{74}$ The Guidance Notes provide that the "benefit" in public benefit can be direct, indirect, tangible or intangible in nature. For the benefit to count, an applicant organisation must demonstrate that there is a link between (a) its charitable purposes, (b) its activities in furtherance of those purposes and (c) the public benefit arising from those activities. If the link between all three is not clear, the benefit is not relevant in determining whether public benefit is present. Thus, a benefit provided to adults in a community when a school makes its playing pitches available to local sports clubs is not a relevant benefit when the charitable purpose in question is to advance the education of primary school children. ${ }^{75}$

The Scottish test refers to "disbenefit" as opposed to "detriment". "Disbenefit", according to OSCR, refers to harm rather than just a lack of benefit to the public. To be counted against a charity, the disbenefit must affect the public at large. Thus, neighbours of a hostel for the homeless may argue that the charity's presence causes them a disbenefit by affecting property values but this disbenefit will be viewed as a private harm and, therefore, irrelevant. In contrast, OSCR suggests that if a pigeon welfare promotion body was to distribute pigeon feed across all the squares of a city, such action might cause public disbenefit (due to increased numbers of pigeons and heightened health risks) and so might outweigh the public benefit provided by the body. ${ }^{76}$ The OSCR guidance will have persuasive value only in Northern Ireland. Charities wishing to operate in Northern Ireland will thus need similar guidance from the CCNI as to how it intends to interpret the public benefit requirements, a fact acknowledged in the Bill itself. ${ }^{77}$

\section{DEFAULT TRUSTEE POWERS}

One final substantive law difference between Ireland and Northern Ireland relates to the statutory empowerment of charity trustees. Unlike Ireland, Northern Ireland recently updated its trusts legislation with the passage of the Trustee Act (Northern Ireland) 2001. This Act provides trustees generally with default statutory powers of investment and powers to acquire land. The 2001 Act also creates a statutory right for charity trustees to delegate certain decision-making functions while giving the Department of Social Development power to make regulations regarding remuneration of charity trustees. ${ }^{78}$ The Charities (Northern Ireland) Bill 2007 further builds upon these provisions. The Bill allows trustees to purchase indemnity insurance out of charity funds, ${ }^{79}$ empowers the CCNI to relieve trustees and auditors from liability for breach of trust or duty 80 and amends the 2001 Act by giving more specific guidance regarding trustee remuneration. ${ }^{81}$ The legislative

73 The similar Scottish test adopts a holistic approach to public benefit requiring that the overall picture should be one of predominant provision of public benefit through activities in furtherance of charitable purposes. See OSCR, Meeting the Charity Test: Initial guidance for applicants and for existing charities, available at www.oscr.org.uk/guidance.stm (last accessed 10 December 2007) (hereafter Guidance Notes), pp. 11-12.

74 Ibid.

75 Ibid., p. 11.

76 Ibid., p. 15.

$77 \mathrm{Cl}$. 4(1) provides that the CCNI "must issue guidance in pursuance of its public benefit objective".

78 See Trustee Act (Northern Ireland) 2001, ss. 11(3) and 30.

79 Charities (NI) Bill 2007, cl. 74.

80 Charities (NI) Bill 2007, cl. 92.

81 Charities (NI) Bill 2007, cll. 89-91. 
picture in Ireland is far removed from the North's enabling environment. The primary trust legislation in Ireland remains the Trustee Act 1893, which is neither current nor comprehensive. The Irish Charities General Scheme of Bill 2006 attempted to remedy many of the identified deficiencies relating to trustee investment powers, trustee liability, indemnity and remuneration. Yet the Irish Charities Bill 2007 omitted all of these provisions. Ministerial indications at committee stage have flagged the potential reintroduction of sections relating to trustee indemnity and trustee remuneration for nontrust related work at report stage. However, it remains disappointing that no provision will be made in the Irish Charities Bill for default trustee powers of investment and delegation.

\section{Changes to regulatory structure}

Both Ireland and Northern Ireland are introducing major changes to their regulatory structures for charity law. There will be a new regulator in each jurisdiction: the Charities Regulatory Authority (CRA) ${ }^{82}$ in Ireland and the CCNI in Northern Ireland. ${ }^{83}$ These bodies will be responsible for the establishment and maintenance of a register of charities in each jurisdiction and will also oversee the reporting regimes applicable to registered charities. The regulators will enjoy varying powers relating to the investigation of charities and the protection of charitable assets.

\section{REGISTRATION AND ITS EFFECT}

One of the most important innovations in terms of regulatory structure will be the creation of the charities register. A charitable organisation that intends to operate or carry on activities in Ireland will be required to register with the CRA. Substantively, that organisation must prove that it is established for charitable purposes and that it satisfies the public benefit test. Procedurally, it must provide the CRA with copies of its governing instrument and financial accounts, details of its trustees and place of business. If the CRA refuses registration, the disappointed applicant can appeal this decision to a new Charity Appeals Tribunal. ${ }^{84}$ The Irish Bill, also for the first time, decouples charitable tax exemption from charitable status, making the regulator responsible for charity registration. ${ }^{85}$ Revenue will remain the appropriate body to decide whether a registered charity will be entitled to tax relief, though it is expected that a good working relationship will exist between the regulator and the Revenue. 86

In Ireland, registration will entitle an organisation to hold itself out as being a "charity", a "charitable body", a "registered charity" or a "charity registered in Ireland". The implications for foreign charities (for example, English, Northern Irish or Scottish charities)

82 The CRA will replace the Commissioners for Charitable Donations and Bequests, which will be dissolved and the powers of which will pass to the CRA under Pt 6 of the Irish Charities Bill 2007, ss. 73 and 74.

83 See, generally, Pt 2 and Sch. 1 of the Northern Ireland Charities Bill 2007.

84 The Charities Appeal Tribunal is an extra-judicial mechanism to allow charitable organisations to appeal against decisions of the authority without having recourse to the courts. Two of its five members shall be drawn from the ranks of judges, barristers or solicitors. Additionally, the Minister of State for Community, Rural and Gaeltacht Affairs will appoint two further members who have "experience in areas of expertise relating to charities" - see Irish Charities Bill 2007, s. 68.

85 Irish Charities Bill 2007, s. 7, provides that nothing in the Bill "shall operate to affect the law in relation to the levying or collection of any tax or the determination of eligibility for exemption from liability to pay any tax". Note, however that the CRA must consult with Revenue prior to the establishment of the Register of Charities (s. 37 (1), as amended at committee stage).

86 Revenue Commission Collector General, Gerry Harrahill, "Taxation and Charity: Service and Compliance Issues" (paper presented at ICTRG's 16th Annual Conference: Charities Towards 2012 - What's in Store?, Dublin, 8 November 2007). See also s. 31 of the Charities Bill 2007, providing for administrative cooperation between the CRA and other relevant regulators. 
are dealt with in s. 41(6) of the Bill: an unregistered foreign charity will be entitled to refer to itself as a charity in Ireland if it is established in another country under whose laws it is recognised as a charity and it has its centre of management outside Ireland. These foreign charities, however, cannot "occupy any land" or "carry out any activities" in the state. ${ }^{87}$ It remains to be seen how this provision will be interpreted. What is clear at present is that in order to fundraise in the Republic, foreign charities will have to register with the CRA and comply with certain reporting requirements. What is not clear is the extent to which a foreign charity will be able to provide services and administer funding in Ireland, while holding itself out to be a charity, without first registering with the CRA.

With respect to Northern Ireland, cl. 16 of Charities Bill provides that every institution which is a charity 'under the law of Northern Ireland' must be registered in the register of charities. ${ }^{88}$ A "charity" within the meaning of Northern Irish law, according to cl. 1, is one that is established for charitable purposes only and falls to be subject to the control of the court in the exercise of its jurisdiction with respect to charities. Entry on the register of charities provides a conclusive presumption that the body in question is or was a charity for the time it is so registered. The CCNI's decision to register or not to register an applicant organisation can be appealed to the Charity Tribunal. 89

Foreign charities are dealt with in cl. 167, which provides for the regulation of institutions that are not charities under the law of Northern Ireland but which operate for a charitable purpose from or in Northern Ireland. "Section 167 institutions" (which, according to the committee stage debates, will cover English and Scottish charities but presumably will also cover charities established in Ireland that carry out activities in Northern Ireland) will be required to prepare a financial statement and a report of their activities relating to their operations for charitable purposes in Northern Ireland. The DCRGA may, by order, require the CCNI to keep a separate register of these institutions and may grant the CCNI power to apply any of the Act's provisions to such institutions that would otherwise not apply. Any such an order will require approval by resolution of the Northern Ireland Assembly.

\section{THE REPORTING REGIMES - IRELAND}

In Ireland, the proposed reporting regime will vary depending upon whether the registered charity in question is incorporated or unincorporated. All registered Irish charities will be required to submit an annual report to the CRA. ${ }^{90}$ Unincorporated charities must also submit a statement of their annual accounts to the CRA, prepared in line with the requirements of the Charities Act. ${ }^{11}$ Charitable companies will be required to submit to the CRA copies of annual returns already prepared in accordance with company law and previously submitted to the Companies Registration Office (CRO). Since it will be an offence for a registered charity not to comply with the reporting requirements, ${ }^{92}$ foreign charities that register with the CRA will be required to file reports too.

87 See s. 41(6) of the Irish Charities Bill 2007.

88 This wording differs from the draft Charities (NI) Order which had provided in Art. 18 that "Every charity which is established or operates in Northern Ireland must be registered in the register of charities."

89 See Sch. 3 of the Charities (NI) Bill 2007.

90 Irish Charities Bill, 2007, s. 46. According to the General Scheme of Bill the annual report will refer to the activities of the charity during the reporting year and such other information relating to the charity or to its trustees or officers that is necessary to ensure the disclosure on an annual basis of relevant core information responsive to the requirements of accountability and transparency in the public interest.

91 See ss. 42-4 of the Irish Charities Bill 2007, outlining the accounting requirements for unincorporated charities.

92 Irish Charities Bill, s. 46. 
In reviewing the proposed Irish regulation, three problematic areas require further consideration. These three issues arise from the different reporting requirements for charitable entities depending on organisational form and relate to: a) dual filing requirements; b) a loophole with regard to charitable religious companies; and c) lack of audit exemptions for charitable companies that hopefully can be resolved as the Bill progresses. A key tenet for the Irish Government has been to avoid dual filing requirements for charitable companies. ${ }^{93}$ Section 46, as currently written, will require charitable companies to submit to the Charities Regulator copies of annual returns (and auditors reports, where relevant) already provided to the CRO. Technically, since the same information is used, this does not amount to dual filing. Pragmatically, charities are likely to view this as an onerous bureaucratic burden that could be more easily resolved between the regulators in question (namely, CRA and CRO) if a system for electronic transfer of files was established between the two offices.

The second issue relates to a statutory loophole with regard to charitable religious companies. In its reporting provisions, the Irish Charities Bill strives to avoid the necessity for dual reporting. It achieves this aim predominantly by including a rider in each of the relevant reporting sections stating that those provisions do not apply to charitable companies. ${ }^{94}$ Essentially, if a charity is established as a company, then company law takes precedence and the Charities Bill prescribes no additional substantive filing requirements for such organisations. Charitable religious companies, however, fall between the two regimes. Incorporated religious charities are exempt from filing returns under Irish company law 95 because the nature of their activities is sufficiently outside normal commercial activity to justify their exclusion. ${ }^{96}$ Yet, these same bodies will not be required to prepare detailed accounts under the proposed charities legislation either. ${ }^{97}$ Given issues of departmental competence, it may be outside the powers of the DCRGA to resolve this issue independently of the Department of Enterprise and Employment. The fact that company law is currently undergoing major revision, however, makes this an ideal opportunity to re-examine the reporting duties of incorporated religious charities.

The final discrepancy between the two reporting regimes works to the disadvantage of charitable companies. Section 44 of the Irish Charities Bill provides that unincorporated charities require audited accounts only when the annual income and expenditure of the organisation exceeds $€ 100,000$. Below this threshold, it is sufficient to have the accounts independently examined. ${ }^{98}$ Charitable companies, being companies limited by guarantee, are required to have audited accounts, regardless of income level. ${ }^{99}$ Thus, the existing combination of proposed charity and company legislation will impose more stringent auditing requirements on incorporated charities with an annual turnover of less than

93 See DCRGA, Establishing a Modern Statutory Framework (n. 5 above), p. 13, noting: "Arrangements could be envisaged whereby the regulatory body would recognise annual returns filed with the Companies Registration Office or vice versa. In this way, charities which are companies limited by guarantee pursuant to company law as it currently stands would not be subject to dual filing requirements."

94 See, e.g. ss. 42(11), 43(6) and 44(12).

95 See Companies (Amendment) Act 1986, s. 2.

96113 Seanad Eireann Debates, col. 1335, Companies (Amendment) Bill, 1985: committee stage (25 June 1986).

97 S. 46 simply required incorporated charities to send a copy of whatever they submitted to the CRO to the charities regulator. The $\mathrm{CRO}$ accounts filed by incorporated religious charities are redacted and disclose no financial information.

98 Irish Charities Bill 2007, s. 44(2).

99 See General Scheme of Bill, Companies Bill, Pts B3 (Designated Activity Companies) and B4 (Companies Limited by Guarantee) excluding the possibility for companies to avail of audit exemptions that apply to private companies limited by shares. 
$€ 100,000$ than will apply to similar unincorporated charities that come solely under the scrutiny of the CRA. A statutory mechanism is therefore needed to give the Minister of State for Community, Rural and Gaeltacht Affairs, who is in charge of charity regulation, some input into the accounting requirements for charitable companies whether that is to ensure a basic level of filing (in the case of incorporated religious charities) or a proportional approach to audit requirements (in the case of small charitable companies).

\section{THE REPORTING REGIMES - NORTHERN IRELAND}

The proposed reporting regime in Northern Ireland is quite similar to the Irish regime: charities are required to prepare annual accounts in accordance with the Charities Bill, if unincorporated, and the Companies Act, if incorporated. Differences arise, however, with regard to the accounting thresholds. Whereas the Irish Bill uses the $€ 100,000$ threshold as the trigger figure for both the audit requirement and the full accounts requirement, the Charity (NI) Bill operates two separate thresholds. For charities with an annual income of less than $£_{100,000}$ the option exists to prepare a receipts and payments account and a statement of liabilities in lieu of a statement of account. ${ }^{100}$ The audit threshold, in line with the thresholds in the rest of the UK, is set at a higher level. Charities with a gross annual income in excess of $f, 500,000$ or a gross income in excess of $f, 100,000$ and assets with an aggregate value exceeding $f 2.8 \mathrm{~m}$ will require audited accounts. ${ }^{101}$ Given the sizeable differences in the auditing threshold that exist between Ireland and Northern Ireland, these differences may adversely affect Northern Irish charities with significant cross-border presence in the Republic when it comes to filing the required charity returns with the CRA since Irish law will require audited reports at a much lower turnover level.

One innovative feature in the Charities (NI) Bill is the provision dealing with auditors and independent examiners' duty of disclosure to the CCNI. This duty is twofold. Clause 68(2) requires such parties to inform the CCNI in writing when they become aware of any matter that they reasonably "believe is likely to be of material significance for the purpose of the exercise" of the commission's inquiry powers. Provision is also made for auditors and examiners to report other matters falling outside the scope of cl. 68(2) to the commission if the accountant has "reasonable cause to believe [that it] is likely to be relevant for the purposes of the exercise by the Commission of any of its functions". ${ }^{102}$ In such an instance the auditor "may" make a report on the matter to the Commission. The disclosure duty in both cases survives the accountant's retirement or replacement.

The provision of a tiered disclosure standard predicated on "materially significant" information, on the one hand, and "relevant" information, on the other, is a clever safety net that better places the CCNI to garner information from accountants concerning potentially untoward financial practices by charities. Whereas there may be scope to debate whether something is materially significant or not, there is considerably less room for manoeuvre if a lower category of relevancy exists that invites disclosure. In each instance the power is broader than the corresponding Irish provision which requires accountants who have reasonable cause to believe that a charity has committed an offence under the Criminal Justice (Theft and Fraud Offences) Act 2001 to disclose that fact to the CRA. ${ }^{103}$ In stark

\footnotetext{
100 See Charities (NI) Bill 2007, cl. 65(3).

101 See Charities (NI) Bill 2007, cl. 66, with regard to the audit/examination requirements for unincorporated charities and s. 104 with regard to audit/examination requirements for charitable companies.

102 Charities (NI) Bill 2007, cl. 68(3).

103 Irish Charities Bill 2007, s. 52.
} 
contrast to the position in the Republic, ${ }^{104}$ however, the Northern Ireland Bill does not impose any sanctions for an accountant's failure to comply with either reporting requirement, so judgment of the provision's practical effectiveness must await implementation.

\section{THE POWERS OF THE REGULATORS}

One area where the two Bills differ quite considerably relates to the proposed powers of the regulators. When it comes to dealing with charities in general and charitable trustees in particular, the CCNI has greater powers than its Irish counterpart. The Northern Ireland Bill empowers the commission, when acting under its statutory investigatory powers, ${ }^{105}$ to take action on its own motion to freeze charitable assets and suspend or remove charity trustees, ${ }^{106}$ if it is of the opinion that there has been misconduct or mismanagement of the administration of the charity in question and that its assets are at risk. In this regard, the commission can also direct a charity under investigation to take any action that the commission deems expedient in the interests of the charity. ${ }^{107}$ Given the broad nature of the powers given to the CCNI, it is not surprising that the Charity Tribunal for Northern Ireland enjoys equally broad powers to scrutinise the commission's decisions in this regard and to quash or modify the orders made. ${ }^{108}$ Appeals on a point of law lie from decisions of the Charity Tribunal to the High Court of Northern Ireland.

In marked contrast, the CRA enjoys much more limited powers. Although it can appoint inspectors to carry out investigations into a charity's affairs and demand the production of documents, ${ }^{109}$ any action that the CRA wishes to take on foot of such an investigation, unless it is classed as an intermediate sanction (basically name and shame), ${ }^{110}$ requires prior High Court approval. Thus, the CRA needs judicial approval to suspend or remove trustees, ${ }^{111}$ to remove a charity from the register, ${ }^{112}$ to freeze charitable assets ${ }^{113}$ or to issue directions to a charity to take a particular course of action. ${ }^{114}$ Only in relation to the initial decision whether to register an organisation as a charity does the CRA enjoy relatively unfettered rights. It follows that given the limited powers of the CRA to act on its own initiative, the Charity Appeals Tribunal's power of scrutiny is similarly circumscribed to reviewing decisions to register or refuse to register a charity. ${ }^{115}$ These variances in the powers of the CRA and CCNI are due to constitutional law differences between Ireland and

104 S. 52 states that an accountant who fails to inform the CRA where he/she has reasonable cause to believe that a charity has breached the 2001 Act or an accountant who makes a materially false or misleading report to the CRA in this regard will be guilty of an offence under the Act.

105 Charities (NI) Bill 2007, Pt 5.

106 See Charities (NI) Bill 2007, cl. 34.

107 Charities (NI) Bill, 2007, cl. 36.

108 See Sch. 3 of the Charities (NI) Bill 2007.

109 Irish Charities Bill 2007, ss. 57 and 58.

110 See Irish Charities Bill 2007, s. 66, with regard to intermediate sanctions.

111 S. $67(4)(a)$.

112 S. $39(5)$.

113 S. $67(4)(b)$.

114 S. $67(1)$.

115 See ss. 39 (providing a right of appeal for bodies deemed to be "excluded bodies" and removed from the register) and 40 (providing for a right of appeal against a CRA decision to refuse to register an organisation) of the Irish Charities Bill 2007. 
Northern Ireland. ${ }^{116}$ It will be interesting, however, to assess the ramifications of these constitutional differences for the respective regulators' effectiveness in regulating charities. Finally, the decision to divest the Irish Attorney General of his powers over charities in favour of the CRA ${ }^{117}$ marks a break with the common law perception of the Attorney General as protector of the public interest. This initiative has not been followed in Northern Ireland where the Attorney General retains a supervisory role. ${ }^{118}$ Given the reluctance of the Irish Attorney General to intervene in charitable affairs in the past, ${ }^{119}$ it may be that the transfer of powers to the CRA should be welcomed on condition that that the CRA is properly resourced to give effect to these unspecified transferred responsibilities.

\section{Conclusion}

A close study of the charity law reform proposals for Ireland and Northern Ireland reveals common concerns relating to charity governance and regulation that are shared with Scotland, England and Wales. Ireland and Northern Ireland share similar policy objectives in terms of charity regulation: to strengthen the charity sector and prevent fraud. ${ }^{120}$ Provision of a charity register, greater transparency regarding the decision-making process for charitable status, a visible regulator for a sector that engages so often with the public through fundraising appeals and the reputation and continued success of which is based on trust and public confidence, these are all positive steps.

The tasks ahead in both Ireland and Northern Ireland in setting up the charities' register and bringing about a climate of accountability relating to both financial returns and charitable activity should not be underestimated. If done well, there will be great potential for increased public confidence, better internal governance standards in charities and a greater opportunity to showcase some of the wonderful work carried out by charity organisations operating on shoe-string budgets. If time and money are not invested in perfecting and policing the new regimes, there will be onerous new administrative burdens on charities without any quid pro quo for the majority that are already compliant. Different approaches to public benefit and to the specifics of charitable purpose will increase the temptation to forum shop whereas the separate financial accounting thresholds in each jurisdiction will make operating as a cross-border charity more challenging than ever before.

Steep learning curves lie ahead for the newly appointed regulators in both jurisdictions. In this regard, the transition of responsibility for charities must be handled carefully so that the collective, albeit fragmented, wisdom of those currently responsible for charity matters is not lost. This issue will be particularly salient in Ireland with the dissolution of the

116 See Arts 34.1 and 37 of the Irish Constitution, the former laying down the general principle that the function of administering justice is one solely for judges appointed under the constitution; the latter qualifying the former by providing that statutes may authorise the exercise of "limited functions and powers of a judicial nature" by persons other than judges in non-criminal cases. See further on the implications of these Articles, J P Casey, "The judicial power under Irish constitutional law" (1975) 24 ICLQ 305.

117 See Irish Charities Bill 2007, s. 36.

118 See Charities (NI) Bill 2007, cll. 12(3) and 15.

119 See O'Halloran and Breen, "Charity law" (n. 3 above).

120 "The purpose of [the Irish Bill] is to deliver reform of the law relating to charities in order to ensure accountability and to protect against abuse of charitable status and fraud": comments of the Irish Minister of State for Community, Rural and Gaeltacht Affairs on the publication of the Charities Bill 2007. "I believe this can only be a positive development, which will strengthen the charitable sector and protect it from potential abuse": comments of the Northern Ireland Minister for Social Development after the first reading of the Charities (NI) Bill 2007. 
Commissioners for Charitable Donations and Bequests, ${ }^{121}$ the transfer of the Attorney General's responsibilities for charities to the CRA, ${ }^{122}$ and the express limitation of the Revenue's role in relation to charities to that of tax liability assessment only. Likewise, the breadth of powers bestowed on the CCNI presents a new statutory agency with omnipotent powers that will need to be wielded with care if the aspiration of light touch regulation is to become a reality.

Charities' perception of the new regime's success will be based upon their registration experiences with the new regulators, the proportionality of the administrative burdens placed upon them in complying with the new legislation and the extent to which the regulators will supervise charitable activity thereby allowing charities (and the public) to distinguish between well-managed bodies deserving of support and other less-deserving entities. Public perception of the charity regimes, on the other hand, will depend greatly on the user-friendliness of the registers, the responsiveness of the regulators to complaints and the workability of the new fundraising regimes. The last point will be dealt with predominantly by voluntary codes of practice in the Republic in conjunction with a public collections permit system run by the Garda Síochána. Northern Ireland regulation of public fundraising will also be based on a permit system, run by the CCNI. Whether Northern Ireland will opt for a non-statutory code of practice (as is currently proposed in the Republic) ${ }^{123}$ or decide instead to follow the English and Scottish decision to establish a Fundraising Standards Board remains to be decided.

Even if the new regimes work well on both sides of the border, consideration should be given to how we might foster a system of mutual recognition of registered charities, thereby relieving some of the increasing burdens on charities that operate in more than one jurisdiction. Given a shared common law heritage coupled with the presence of crossborder charities, plus jurisdictional penchants for resolving similar problems differently, greater practical cooperation between charity regulators should be encouraged. One step forward would be to give formal recognition to the UK and Ireland Charity Regulators' Forum. Created in 2006, this body, comprising of officials from OSCR, the English Charity Commission, and the charity units from the relevant government departments in Ireland and Northern Ireland, seeks to encourage co-ordination of and consistency in regulatory approaches in the UK and Ireland, share information and best practice on charity regulation, and encourage effective working relationships between the devolved administrations responsible for the regulation of charities. The forum, which as a concept finds support in EU law, ${ }^{124}$ is a welcome supplement to existing memoranda of understanding between certain regulators. ${ }^{125}$ It is to be hoped that in its twice yearly meetings this body might formally take up the challenge of reducing some of the unnecessary differences that exist between the two jurisdictions so as to stimulate greater cross-border charitable activity without increasing the regulatory compliance burden on law-abiding charities.

121 Irish Charities Bill 2007, Pt 6.

122 Irish Charities Bill 2007, s. 36, In contrast, in Northern Ireland, the Attorney General will continue to act in his role of parens patriae with regard to charities, see cl. 12(3) and s. 15 of the Charities (NI) Bill 2007.

123 See Irish Charities Tax Research, General Statement of Guiding Principles for Fundraising (Dublin: ICTR, May 2008) and Final Feasibility Report: Regulation of fundraising by charities through legislation and codes of practice (Dublin: ICTR, May 2008) at www.ictr.ie (last accessed 3 June 2008).

124 See European Commission Communication on The Prevention of and Fight against Terrorist Financing through Enhanced National Level Coordination and Greater Transparency of the Non-profit Sector, COM(2005) 620 final (Brussels: 29 November 2005).

125 See www.oscr.org.uk/ukandirelandcharityregulatorsfor.stm. See, e.g. Memorandum of Understanding between the Office of the Scottish Charity Regulator and the Charity Commission (June 2007). 
